\title{
Factors roles in Communication and Effective Teaching for the Fourth Year students in Modern British and American Novel lesson classes and their Impacts on Students' Motivation. \\ Asst. Prof. Dr. Juan Abdullah Ibrahim Al-Banna \\ Dept. of English. College of Languages \\ Salahaddin University/Erbil \\ banaali_juan@yahoo.com
}

\begin{abstract}
:
Motivation was and still is the aim of each instructor in teaching. No matter what mood or psychological state both the instructor and the students undergo during lecturing, still there are crucial academic processes that improve the students' state and affect their process of motivation. Depending on certain pedagogical theories, modern experiences and techniques and applying them during lecturing,the researcher hypothesizes that certain factors are necessary for encouraging and keeping the students highly motivated. Such factors include, variety in the style of teaching, the ability of the instructor to comprehend and respond to each level in the class. Responding to the students' need concerning a suitable curriculum and presenting certain facilities like key words to motivate them and maintaining a good relationship between the instructor and the students by giving them chances to express their views especially when it is related to the cultural aspect of the British or American text and the students' own culture. Choosing modern approaches like new criticism, the reader-response theory, the analytical procedure and stylistic approach will be necessary to be applied on the modern novels. A questionnaire of twenty items are distributed among forty students of fourth year for two groups to observe the students' feedbacks and motivation. The aim of this research is to minimize the barriers of communication and create an effective atmosphere for teaching in the class. Another important aim is to realize the significance of literature through modern theories and techniques which reflect our life, specially Modern Novel.
\end{abstract}

Keywords: Pedagogy, Theories \&Techniques, Modern Novel, Motivation ,Activities. 


\section{دور(عوامل معينة مهمة ومؤثرة لتعليم الطلاب تحفيزهم في مادة الرواية البريطانية والأمريكية الحديثة

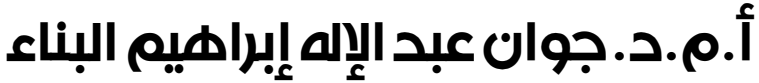

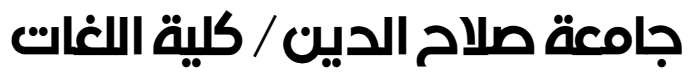

الملخص إن تحفيز الطلاب على التعليم كان و لا يزال هدف كل تدريسي مهما كانت الحالة النفسية للتدريسي و الطالب اثثاء الدرس ، الا ان هناك خطوات اكاديمية ضرورية لتحسين الوضع العلمي للطلاب معتمدا على نظريات تعليمية

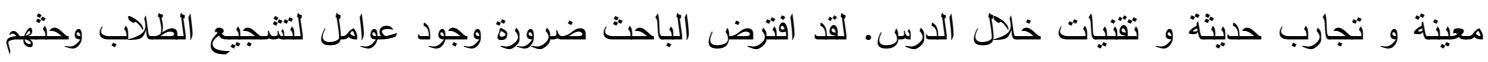

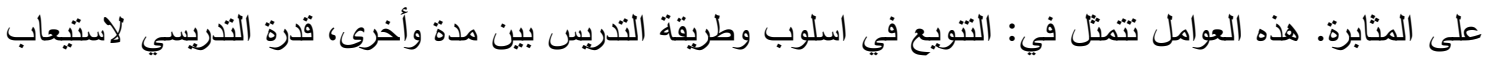
مستوى الطلاب واقامة علاقة طيبة معهم، والاستجابة لاحتباجات الطلاب، من حيث اختيار منهج مناسب وتقديم توضيحات معينة في اثثاء الدرس كمفردات (المفتاح) لتفسير محتوى المادة و المنهج واعطاؤهم فرصة للتعبير عن من هن

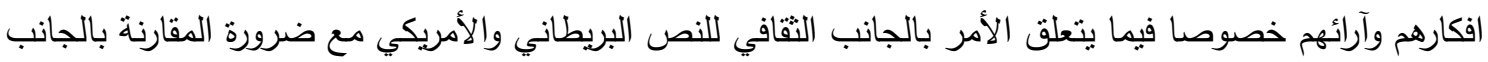
التقافي للطالب. وإن اختبار مفاهيم ونظريات نقدية و حديثة ، ونظرية الاستجابة للقارئ و الخطوات التحليلية و

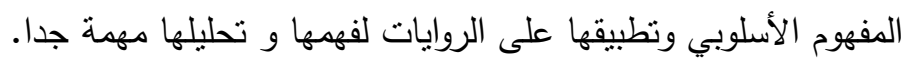
قام الباحث باختيار عشرين سؤالاً واختار اربعين طالبا من مجموعتين. ثم دون مدى استجابتهم لكل المواد

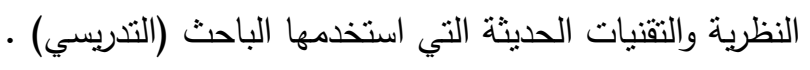

ان هدف هذا البحث هو للتقليل و ازالة العقبات التي تعترض مسيرة التعليم و خلق جو اكاديمي في اثثاء الدرس. هناك هدف اخر ايضا مهم وهو الهمية مادة الأدب و ضرورة نوضيح العوامل و النظريات الحديثة و مساعدة

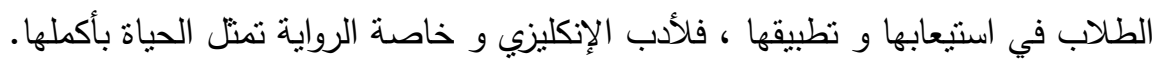

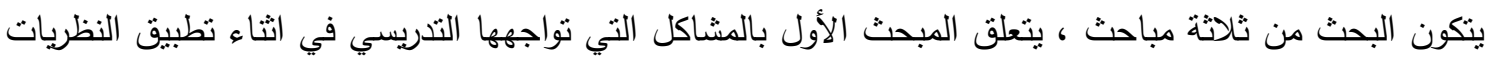
والمدارس النقدية الحديثة على النصوص الادبية (روايات القرن العشرون) ، اهمية هذا البحث و اهدافه وطريقة

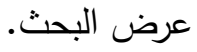

المبحث الثاني هو عبارة عن عرض للجانب النظري و اهمية المفاهيم المستخدمة في تدريس الرواية الانكليزية الحديثة مثل النقد الحديث و الرواية الحديثة، المفهوم الأسلوبي وتحليلها، مدى تأثنير هذه المدارس على الطيه الطلاب واستجابتهم في اثثاء قراءة واستيعاب النص، الخطوات التحليلية ومكوناتها من حيث الحبكة المقنعة و التشخيص المتباعد، تقديم تقسير مفصل لمجريات الحدث، ونثر تثبيهي، ثم كيفية تحليل النصوص معتمدا على كثرة استخدام

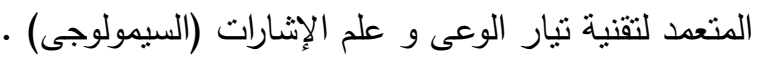
اما المبحث الثالث والأخير ؛ فيتعلق بتتويع التدريسي في اسلوبها بين فترة و اخرى وملاحظة تأثير ذلك في الطلاب

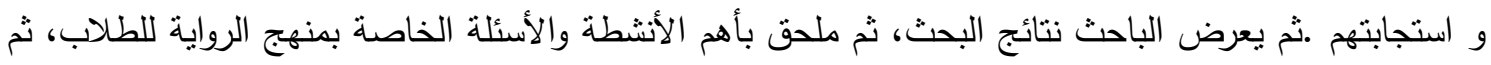

عرض اهم المقترحات يليها قائمة بأسماء المصادر التي استخدمت في البحث واخيرا الملخص باللغة العربية. الكلمات المفتاحية: التعليم ، النظريات والتقينات، الرواية المعاصرة، الفعاليات التحفيزية. 


\section{Introduction:}

Novels in general are important literary texts that affect students' attitudes of developing their cultural aspect and learning a lot about the foreign language through English texts. Peter Prince (2009) claims that it could be argued that fiction has been a component of EFL course books since the 1950s or earlier when dialogues were attributed to characters, generally belonging to a 'typical' British or American family, engaged in everyday activities. Whether this counts as fiction depends on one's definition of the term: the narrative elements were limited and there was no plot as such, the 'stories' being self-contained within each unit, rather than spread out through the book to form a single narrative (qtd in Gardner, $2011: 225$ )

This is exactly the feature of modern novel when concentration is on characters rather than plots, on conversation among characters that create realistic situations. This research aims at showing students' opinions and activities in the modern novel's lesson. It clarifies how a group of students respond to different pedagogical processes while their instructor conveys messages about various modern approaches in teaching them modern British and American novel. They also respond to each different style that the instructor teaches them. The research was conducted in a group of (40) students who are randomly selected from total number of (83) of two groups of the Fourth Year, in the English Department/College of Languages (2015-2016). The researcher started to evaluate the students' activities from the first day of the semester till 24th of February, They were asked to give their views about their background knowledge of the modern age. After few weeks of studying, commenting, explaining views about modern movements which appear during the transitional period of the mid Nineteenth century to the Twentieth, the researcher constructed a questionnaire form about features of modernity, different approaches for studying and applying specific techniques of the modern age. Also a part of the study is concerned with making a comparison and state their views in case of finding any cultural differences. Arguments with the students will encourage the communicative process. Another style of questions will be through messages sent to the students, in this case the researcher will get their responses either from phone messages or emails. The research data were analyzed by the percentage statistical formula by which students' responses frequencies collected and calculated. Research results revealed that before giving them the theoretical background about the modern approaches of the New Criticism, The reader- Response and The stylistic Approach, the students' were not able to analyze the two modern novels of 'Gertrude Stein's' (1909) Three Lives and 'George Orwell's' (1977) 1984. They were also not able to pinpoint the techniques and understand 
why writers overuse certain technique rather than another. Due to the results of this study, the researcher presents certain suggestions.

\section{Section One}

\subsection{Problems of teaching a foreign language during the application of modern theories on modern British and American Novels}

Students face difficulty in understanding the way certain techniques are applied on the literary texts, in other words, the curriculum chosen in this study. Al-Jezaire (1987:87) believes that teaching literature has become a mechanical process by which the students could learn pieces of information to be recommended in the necessity. In her view, a certain proportion of students graduate without having attained many of the objectives that lie behind literature (qtd in Al-Azzawi 1).

It is necessary to provide the students with information and suitable theoretical approaches and practice them on the texts selected by the instructor. This study aims at clarifying the way such theories apply on the texts during teaching methods. The instructor tries to ask them and take their feed backs to be sure which method or technique will convey the right message needed in the process of learning which leads to be independent and promote their autonomous learning. Another problem lies in the fact that most of the students commit mistakes in spelling, in using the correct tense, suitable vocabulary in the process of the analytical procedure.

In order to achieve efficiency, students have to understand the style of the novelist and be aware of certain terms and techniques used by the writer. They also have to understand the thematic and cultural aspect of the era of a given novel.

Here comes the role of the modern reader-response theory and the stylistic analysis approach in which it takes into consideration the language used by the author, and the way of using certain linguistic elements. The study of literature has been associated with the realm of experience, and terms like 'feeling' and emotion' where the reader is supposedly able to identify with the experience contained within the literary text, or with that of the writer transmitted through the text (Webster,1990:10).

The use of new approaches will create a change even in the style of teaching, such stage will invite the reader to have new activities inside the classroom. The new communicative approach will be of help for both the teacher and the student as well. Thus students find themselves in front of series of responsibilities and activities of language teaching rather than being a passive listener. Michael Byram\& et al, (2002: 43) defined intercultural teaching dimension as "that dimension in language teaching that aims at developing learners as intercultural speakers or mediators who 
are able to engage with different identities to avoid the stereotyping of a single identity ( qtd in Al- Azzawi ,2015 : 2).

\subsection{Significance of The Study}

The significance of this study lies in the role of various techniques used in teaching English modern novels because each educational process should follow certain techniques to obtain the aims. Using various techniques in teaching, will help the students to be selective and more experienced and this make them depend on themselves in the discussions during the daily activities that will lead to create a positive atmosphere of learning. Another significance is that the learners will get used to analyze a piece of text getting benefit from the instructors notes in selecting important paragraphs that carry the novelists messages and expressing their own viewpoints and being able to pinpoint differences and similarities between the English and their own cultures.

\subsection{Value of the Study:}

The study aims at :

1- Showing the suitability and the contrary effect of using various techniques used in teaching Modern Novel at the college of languages, English department, Fourth year students in the light of the results of the students feedbacks and the questionnaire and the evaluation of the teacher.

2- Answering the following questions:

a- What are the main pedagogical methods used by the instructor?

b- Do the approaches used in studying and analyzing the novels emphasize on the language or on the British and American text as a fiction, or do they reveal the stylistic features?

c- Which modern approaches or techniques are mostly favored by the students?

\subsection{Research Design and Method}

This qualitative study aims at investigating student's abilities while analyzing a modern text. The form of the questionnaire is divided into three parts. The first part is related to the strategies of pedagogy, it takes nine items, the second part is about the strategies of speaking which is specific to language, it takes three items. The other four items are specific to the questions about our intuitions, feeling and passion. The remaining four items takes important activities into consideration. Students were asked to respond to statements or answer the questions by yes or no or clarify their points of views exactly or relatively or they choose neutral scale. This study evaluates the students' feedbacks and reaction to different 
methodologies for teaching Modern Novel. The data collected based on questions, interviews, giving brainstorming assignments in the class. Depending on the reader-response approach, the researcher provides the students with various samples from both novels and provides them with ten techniques written on a sheet of paper, to give the students a chance for applying and finding these techniques in the parts of these given samples. Another teaching method is to write down key words on the board and discussing them with the students. Quizzes every two months once will give the instructor a chance for checking and evaluating the students' levels. Specifying time at the end of each lecture to apply the theoretical approaches that we discuss during lecture on the text is necessary. Another method is to give assignments through email addresses to give them views for learning how and when to be critical?, this will help students to depend on themselves and play the role of a critic .Giving a couple of students chances for presenting a seminar about one of the topics is also important.

\section{Section Two: Theoretical Background:}

\subsection{New Criticism And Modern Novel}

Modern English Literary texts whether British or American should be analyzed according to New approaches in criticism. Booker (1996 :13) claims that the new Criticism approach, which involves the close and careful reading and interpretation of individual literary texts, has its roots in the 1930s; the label New Criticism itself derives from the title of a 1941 book by john Crowe ransom, one of the leading founders of the movement...many of the assumptions and techniques of the method became almost synonymous with criticism itself; characteristics such as close reading and detailed interpretation of specific texts were eventually broadly perceived as central to the critical enterprise.

As Rubin Jr. (1980: 106) puts the matter, we are now in a post-New Critical age only in the sense that the New criticism "has become simply criticism". Many college students are essentially New Critics without even knowing it , and the same might be said for many of their teachers. Thus as Cain (1984) notes, the New Criticism may now seem powerless "only because its power is so pervasive that we are ordinarily not even aware of it" (105).Finally even critics who recognize this power and assiduously attempt to escape it in their own criticism often find themselves slipping into New Critical practices in their teaching because such practices are so well suited to the classroom environment (Booker 14). The new Criticism is a "formalist" approach to literature-that is, it pays close and careful attention to the language, form and structure of literary texts while regarding individual texts as the principal object of critical investigation. The New Critics, argued that the meaning of literary texts resides primarily in the texts themselves rather than in their historical context. The New 
critics insisted that literature has to be read in special ways because style, form, and technique play roles in literary texts that are different from the roles they play in ordinary discursive texts (ibid).

Bressler (2007) claims that by the beginnings of the Twentieth Century, emphasis was textual analysis again shifted to the text. With the advent ofon New Criticism, the text became autonomous, an objective entity that could be analyzed and dissected. If studied thoroughly, the new Critics believed, the text would reveal its own meaning. Extrinsic factors, such as historical or social context, mattered little. Now considered a verbal icon, the text itself, declaredthe New Critics, contains what is needed to discover its meaning. We need only master the technical vocabulary and the correct techniques to unlock it (76). Life experiences of the reader in Bressler's view provide a kind of reality check for the reader, either validating or negating the authenticity of the experiences as represented in the text. By doing so the reader is no longer the passive receiver of knowledge but is instead an active participant in the creation of a text's meaning (78).

The instructor has to provide the students with the suitable theory to be applied on the novel under analysis. For example the two modern novels : Three Lives by Gertrude Stein and 1984 by George Orwell can be understood in the light of the application of new critical approaches to the modern age in which both texts are written.

\subsection{Modern British and American Novels:}

One of the reasons that made literary critics of fiction to remove the interest from the sociological novels of Wells, Bennet, and Galsworthy and fixed the interest on novels and novelists of a very different kind was because of the First World War. Virginia Woolf (1882-1941) attacked Bennet because he concentrated only on the externals : dress, occupation, age, money. She made her effort to concentrate on the inner aspect and life of the mind of the character Abbot et al (2004: 1075). E.M. Forster (18791970) also defended personal relation, he provided a broad view of people and society but his characters are people tempted to withdraw into a private inner circle where they can enjoy warmer feelings. His novel A passage to India and his Aspects of the Novel (1972) is still one of the best introductions to the subject.

On the other hand, D.H. Lawrence (1885-1930) looks inward not to show us a stream of impressions, but to explore mysterious areas of feeling of which we are hardly conscious. But the great experimenter of the modern age is James Joyce (1882-1941). He too dug into the complexities of the unconscious mind. Another novelist was Aldous Huxley (1894-1963), who was a successful novelist. Other modern British novelists were Evelyn Waugh (1903-1966) who was concerned with humour. Graham Green (1904-1991) whose concern was to write about good and evil. 
Today, most readers prefer George Orwell's topic of unemployment and dictatorship as it is clear in this research paper that our fourth year students were highly impressed by reading his political novel entitled as (1984) and Animal Farm. The more we proceed with the British fiction we approach the theme of subjectivity in which it takes into considerations complex topics about autobiographical aspects and the importance of the self and psychological aspect of an Individual. The student is supposed to know these before graduating from the college. To understand the modern novel of George Orwell and his style, the student has to be aware of the modern techniques that will enable him to understand the dystopian aspect of the miserable modern man like Winston.

Concerning the style of the modern British novel, it concentrates on the spoken form rather than the written ones. During Nineteenth century concentration was on the historical cases of the dialects whereas nowadays progress in technology made us be attracted to the spoken form. As Abbot et al (2004:1077) states that The themes of the social class becomes ineffective for due to the increasing democratization of society and the concern for the individuality made the modern man more conscious about his reality. The modern fiction style nowadays is paying attention to the spoken form of literary texts which pushes the reader nearest to reality.

During the last hundred years the United States has attained a position of world leadership in material wealth and industrial and technological accomplishment. Abbot et al (1996:564)believes that The most powerful nation on earth, it has achieved the greatness for which it has always destined. Two World Wars (1914-1918) and (1939-1945) shook and altered the world .In spite of the fact that it emerged victoriously from both world wars but it experienced a massive depression. Individuals felt isolated, no longer bound to each other by traditional standards of conduct or by the structure of society. Contemporary American writers express the separateness of the self and the modern sense of isolation and alienation. Another feature that American writers mostly tackle is the aspect of culture. The reader observes a diverse cultural aspect in Gertrude Stein's novel Three Lives .Stein writes about different nationalities and cultures and presents a complicated picture of an individual who feels upset by the fear of death. She presents a view of the German voice through Liza, Anna and other women. She also sheds lights on the black African American women then she makes comparison among all these cultures and criticizes racism when Stein presents depressed views about Melanctha, a girl of white mother and black father. She is always threatened because the society does not accept a blue girl. Both American and British modern novelists present their views in an indirect way. Their styles are mysterious and difficult to express the difficulty of the psychological state of the protagonists in the 
novels. The problems of racism, unemployment, colour discrimination, violence, freedom are all American contemporary themes. Other American writers have written about war and terrible fear of deathlike, Ezra Pound (1885-1972), Robert Frost (1874-1963), T.S. Eliot (1888-1965)(See Adventures in American Literature, pp568-569). Experimentalism, realism. Absurdism. Expressionism, modernism, futurism and other movements arise to express such notions about self and traumatic incidents that led to the appearance of different schools like confessionals represented by Sylvia Plath whose American, free style had really affected the world. Towards modern age, the writers were no longer able to stick to the spiritual aspect of the Victorian or post Victorian age, materialism was the movement that opportune spiritualism. War and progress in technology widened the gap among individuals. So to comprehend the modern British and American novel, writers, students, novelists should realize that the modern techniques are the only means to understand the modern fiction and style.

\subsection{The Stylistic Analysis Approach}

According to Cuddon (1984: 663), Style is the characteristic manner of expression in prose or verse; how a particular writer says things. The analysis and assessment of style involves examination of a writer's choice of words, his figures of speech, the devices (rhetorical and otherwise), the shape of his sentences, the shape of his paragraphs - indeed, of every conceivable aspect of his language and the way in which he uses it. Style defies complete analysis or definition because it is the tone and 'voice' of the writer himself; as peculiar to him as his laugh, his walk, his handwriting and the expressions on his face. Stylistics A kin to linguistics and semantics, it is an analytical science which covers all the expressive aspects of language: phonology, prosody, morphology, syntax and lexicology .

Sopher (1974:63) defines stylistics as 'the linguistic analysis which takes into account every factor contributing to meaning, content, organization , vocabulary, syntax, morphology and phonology'. The central purpose of stylistic analysis of the fictional text is to demonstrate in concrete terms, both what has been communicated and how it has been communicated. Since literary communication operates through language, all literary analysis rests ultimately on linguistic analysis (qtd in Al-Azzawi 14). In this regard, Rodger (1969) stated that "our task as English teachers is...not to hand over predigested meaning, and concepts, but to teach our students to read and interpret for themselves by themselves... to be reasonably skilled and sensitive readers, able to feel and judge for themselves, with fidelity to the textual facts, in response to any work of literature they may choose to read..."(89).

Widdowson (1975: 54), giving a need and justification for stylistics, says that a literary critic appeals to intuition to grasp the artistic value of a text 
but the reader may not share this intuitive judgment. Stylistics fills this gap by finding those patterns in the text on which intuitive aesthetic appreciation depends. Thus stylistics is a bridge between trained intuition of a critic and novice observation and reading of a common reader (qtd in Gulam 8).Jeoffy hall (2007) claims What is known of the contribution stylistics might make to the aims of this more widely conceived literary, cultural and general language education, empirically, as opposed to asserted or speculated, as will appear, is rather thin. What we all need to understand better are the possibilities for stylistic interventions in our own classrooms and curricula. Especially, I shall argue, in the light of new understandings of language and of language learning, as well as of literature, we need to understand how such localized investigations can contribute to the bigger picture of a renewed understanding of the workings of stylistics in second language educational contexts (qtd in Watson \&Zyngier 3).

\subsection{Students Response and their Reading Experiences}

One of the theories that the researcher wanted to apply on the two modern novels is the reader-Response theory .This theory has been established in 1960s.Drabble (2002) defines it as a body of literary investigations, chiefly American and German, into the nature of the reader's activity in understanding literary texts(246). Since the two novels are written in the twentieth century, the reader-response theory can be applicable. The students, here as readers of the two novels make their ways through the novels, encountering various stylistic devices and reacting by stating their views after reading the two literary texts. Stanley Fish (1982) is one of famous critics of the reader-response theory who illustrates the importance of readers observations by discussing examples from the text (42).

The reader, here, our students observes and compares the description of the characters mentioned in the text like Stein's female characters Anna, Rose, Lena, Melanctha and others, establishing their own views. They will try to link what they interpret with what they believe it reasonable, even contrary to the writer's. Sometimes the readers are disappointed with some of the situations and interpretations of their own. According to Fish, it is such sequences of anticipations, disappointments and reevaluations on the part of the reader that constitute the most important object of critical inquiry. Fish believes that critics should not focus so much on interpreting the meaning of the text as on describing the reading experience. They should concentrate not on what these texts mean but on what they do (Ibid).

For Fish, the text, and even the individual sentence "in no longer the object, a thing-in-itself, but an event, something that happens to, and with the participation of the reader" (25). Thus despite his focus on the activities 
of the reader, Fish continues to grant a great deal of importance to authorial intention and the role of the text in provoking the reader's responses. For this reason, affective stylistics is sometimes referred to as a "text-active" approach to reader-response criticism.

\subsection{The Analytical Procedure and the Modern novel}

Cuddon in A Dictionary of Literary Terms defines "Analysis" as a detailed splitting up and examination of a work of literature. ...Analytical criticism helps to make clear an author's meaning and the structure of his work. It is argued that analysis spoils an intuitive and spontaneous response to a work of literature. Those in favor of 'deep' analysis contend that, on the contrary, it enhances the reader's enjoyment (39). Many critics of modern age startedto comment on certain procedures among them is Graham Martin who believed that some modern novelists depended on the analytical procedure in their texts rather than symbolism. The two modern texts in this research share most of the techniques used in this analytical approach that martin had claimed and these include:" distanced characterization, significant description, multiple point-of-view narrative, 'credible' plots" and "metaphorical prose (qtd in Ford, 1984:421).

Students should understand the points included in this procedure and try to apply them on the modern texts during class activities. For example , presenting a character indirectly, providing useful information, having more than one view and in conflict with others, and realistic problems and the use of certain words as a metaphor along the paragraphs are all featuring modernity.

\subsection{Modernity and Stream of Consciousness}

According to Cuddon the technique of stream of consciousness is a term coined by William James in principles of Psychology (1890) to denote the flow of inner experiences. Now an almost indispensable term in literary criticism, refers to that technique which seeks to depict the multitudinous thoughts and feelings which pass through the mind (661). For example, Stein writes:

Every day now, Jeff seemed to be coming nearer, to be really loving. Every day now, Melanctha poured it all out to him, with more freedom. Every day now they seemed to be having more and more, both together, of this strong, right feeling. More and more every day now they seemed to know more really, what it was each other one was always feeling .More and more now every day Jeff found in himself, he felt more trusting .More and more every day now, he did not think anything in words about what he was always doing. Every day now more and more Melanctha would let out to Jeff her real, strong feeling (Three Lives 109) 


\subsection{Semiotics}

Barthes(1964:1) in Elements of Semiology claims that in his Course in General Linguistics published in 1916, Saussure postulated the existence of science of signs or semiology of which linguistic would form only one part. Therefore, semiology aims to take in any system of signs whatever their substance and limits; images, gestures, musical sounds, objects or complex association of all these which form the content of ritual convention or public entertainment. Semiotic method, as Barthes argued in his 1957 masterpiece Mythologies, is fundamental because, unlike other approaches to media, it focuses almost exclusively on hidden meanings (Danesi viii). As an example George Orwell writes:

For the moment it was too difficult to go on. He shut his eyes and pressed his fingers against them, trying to squeeze out the vision that kept recurring. He had almost overwhelming temptation to shout a string of filthy words at the top of his voice. Or to bang his head against the wall, to kick over the table and hurl the inkpot through the window- to do any violent or noisy or painful thing that might blackout the memory that was tormenting him (1984:63)

\subsection{Allegory}

The term derives from Greek allegoria' speaking otherwise'. As a rule, an allegory is a story in verse or in prose with a double meaning: a primary or surface meaning; and a secondary or under-the-surface meaning. It is a story that can be read, understood and interpreted at two levels. An allegory has no determinate length. George Orwell's novels especially Animal farm and 1984 are allegorical see Cuddon : 24). The following refers to George Orwell's allegorical reference to Stalin and his dictatorship against his own people:

His mocking eyes roved over Winston's face. "I know you," the eyes seemed to say, 'I see through you, I know very well why you didn't go to see those prisoners hanged,' in an intellectual way, Syme was venomously orthodox. He would talk with a disagreeable gloating satisfaction of helicopter raids on enemy villages, the trial and confessions of thought-criminals, the executions in the cellars of the Ministry of Love (1984: 49) 


\section{The Instructor's Role in Variation of the Teaching style}

The process of teaching is not easy ,because creating a communicative, academic atmosphere inside the classroom is in need of many procedures that should be followed. There should be one to one correspondence between the instructor and the student, negligence on any part will be a barrier in this process of communication. The researcher experiences different modes in the style of teaching to reach at reasonable results suitable for both parts, the teacher and the student. Introductory first two weeks in the first semester is crucial. These two weeks should provide the students with references and information about the features of modernity, what is meant by 'a modern text", who were the pioneers in this field?. Then the instructor provides the students with the name of the references that are supposed to be read. Asking and answering questions mutually is one of the styles for directing the lecture. Another style is to ask the student to explain the material that is specific for that day as a students assignment. The instructor can also direct the teaching method through showing slides and explaining what do they denote?. Another style would be to write down important "Key Words" that carry the message of the author and present views for stimulating the reader. Other style is to give chances of one or two students to present a seminar of no more than ten minute every two weeks as a means for motivating the students and creating an atmosphere of competition among them.

\subsection{Language and Theme in Gertrude Stein's Three Lives}

The samples chosen should represent the style of the writer and the themes attached to it. Ann Charters (1990: xv) claims that Stein was working on Three Lives, James Joyce, another expatriate author important in the history of modernist literature, was beginning his career, writing the stories of Dubliners. Stein's break with the conventions of storytelling was more sweeping than Joyce's rebellion against his predecessors, since her first published book she broke from the tradition of realistic fiction to a far greater degree than he did in Dubliners. Her stories of uneducated, working class characters in Three Lives aren't presented to expose the spiritual bankruptcy of commentary society. By her account they were invented to demonstrate theories of aesthetic composition, existing on the page without social or political implications. They are fictional characters who strike the reader as living in a world of their own, a world determined by an aesthetic not a social order. In one of her later essays she said the key to understanding her books was realizing that she wrote "by ear" rather than " by eye, " not imagining pictures of what she was describing in words but concentrating on hearing the words she was putting down on paper, thereby achieving in prose what she called a "continuous present". The way her ear 
dominated the language and tone of narrative in "The Good Anna", " Melanctha" and "The Gentle Lena" is easily appreciated. We are in a woman's world in Three Lives, one in which women's voices are heard expressing their inner feelings, wishes, moods, ideas, and confusions, and above all else, earnestly advising one another the best way to live. Because plot action in the stories is virtually static, Stein depended on simple, concrete language and a carefully nuanced tone to move the narrative(Ibid: $\mathrm{XV}$-XVI).

Another outstanding feature of Stein's style is the omission of commas is a recurrent device. Lodge (1984:193)in his book 'Language of Fiction' claims that the effect is to abolish any logical order or variation of emphasis in the series, and to suggest a complex but instantaneous response. It anticipates the attempts of later experimental novelists, like Joyce and Gertrude Stein, to impose simultaneity upon the linear medium of language .

When reading Stein's novel about three women of different nationalities and colors .Each of these female characters are explained differently but in all of them the aim is a call for women voice. It is about these women's sufferings, agonies and everyday life. This novel can be analyzed depending on a feminist stylistics.

Widdowson claims that stylisticians claim the usefulness of stylistics in the foreign language classroom. Stylisticians began to direct their attention to how a piece of narrative work exemplifies the language system, so they have treated novel as a "text" or a "message'. Stylisticians claim that stylistics help students to appreciate novel since "linguistic analysis" helps to make intuitions which help them to talk about the novel more articulately (Chatman 54).

\subsection{Results of the study:}

1. Most of the students preferred writing Keywords on the board and discussing them.

2. All the methodologies used in teaching literature are beneficial and crucially important. But the degree of student's response towards a method differs from stage to another and student to another.

3. Only fourteen students in one group were motivated and participate in most of activities successfully. But in the other group only nine student's activities were outstanding.

4. Thirteen students were active in most of daily activities and respond to: seminars, techniques, discussions, comparisons about cultural aspects whereas only seven students respond to the activities.

5. Concerning the whole no of the students in one group of twenty students only nine students comprehend the approaches and their 
application on the novel. Whereas only ten students out of twenty initiate and are indulged in activities.

6. Eighty percent of the students did not comprehend the message of the writer.

7. Thirty-two students out of forty achieve success in comprehending the ten techniques.

8. The students did not respond to comprehend the critical approaches towards studying \& analyzing the novels.

9. Most of the students were ignorant of defining stream of consciousness \& metaphorical prose.

10.Ninety-five refused learning through slides of the data-Show.

11.Most of the students follow the traditional structural approach in memorizing the facts.

12.Few students' responded to present seminars and most of them preferred to be presented by the instructor.

13.During Quizzes and Exams, the students commit mistakes related to their uses of correct spelling, tenses and other mistakes in writing.

\subsection{Conclusion:}

The main message the researcher gets at is the importance of the new critical schools and practicing new modern techniques on the texts under analysis. The results of the questionnaire refer that most of the students have similar views and feedbacks about which pedagogical method they prefer and which modern technique they comprehend and prefer. Students all prefer learning through key words, responding to the assignments related to the modern techniques. But they entirely refuse to learn through projector or listen to their colleagues seminar, only very few students respond to this activity.

Giving chances to the students to trust their abilities and express their views about various pedagogical methods of learning, and expressing their views about differentiating between their own culture and the foreign culture led them to feel free and trust themselves and turn to a critic. Through communicative way of interaction, the students' were able to learn from their own mistakes or from their colleagues which helped them to know more about their own cultural and linguistic capacities that helped them to develop their abilities.

\subsection{Suggestions and Recommendations:}

Due to the results, the researcher suggests the following:

1- Encouraging English Departments to determine a curriculum of New Criticism so introduce Fourth year students to study Modern approaches that help them to understand the way the modern literary texts are written.

2- Encourage Instructors of literature to provide the Fourth Year students with theoretical background of modern approaches. 
3- The Successful teacher is the one who deal with his/her students as a member of a family and try hard to change his style to suit the students' abilities.

4- Stimulating the students' and responding positively to their feedbacks is a serious step towards effective teaching that will definitely motivate the students towards positive results.

5- Using various methods and applying new ones is a must.

6- The teacher should respond to the students' feedbacks and try to take them into consideration and this will increase the teacher's pedagogical abilities.

\section{References:}

1. -Abbot, L et al.(1996). Adventures in American Literature.USA: Holt, Rinehart and Winston.

2 . (2004).Adventures in English Literature. USA: Holt, Rinehart and Winston.

3. -Al-Azzawi, N .J.A. (1993) A Study of Teaching Techniques used by Instructors of the Novel in the department of English, University of Baghdad.

- -----------(2014).Investigating EFL learners' attitudes towards using project- based learning as a means of promoting their autonomous learning. Journal of the College of basic education: Al-Mustansiriyah University.Vol.20. No:83..

4. -Al-Jezari, Kawther .(1983). The Role of Literature in Teaching a Foreign

5. Language.Al-Mustansiriyah Journal of Arts. Al-Mustansiriyah University Press.

6. -Barthes, Roland.(1964).Elements of Semiology.Hill \&wang.

7. -Bressler, C.E.(2007). Literary Criticism. New Jersey: Pearson Prentice Hall.

8. -Booker, M.K. (1996). A practical Introduction to Literary Theory and Criticism. USA: Longman Group LTD.

9. -Brooks, N. (1964). Language and language Learning. New York: Brace and Word INC.

10. -Cain, William E. (1984). The Crisis in Criticism :Theory, Literature, and reform in English Studies. Baltimore, MD: John Hopkins UP.

11. -Charters, A.( 1990). Introduction.USA: Viking Peniguin. ).

12. -Danesi, M. (2002).Understanding Media Semiotics.USA: Oxford University Press.

13. -Drabble, M. (2002). The Oxford Companion to English Literature. Great Britain: Oxford University.

14. -Cuddon, J.A. (1984). A Dictionary of Literary Terms.U.S.A.Penguin Books Ltd.

15. -Fish,S. (1982).Is their a text in this class?The Authority of Interpretive Communities.Cambridge,MA: Harvard University Press.

16. -Ford, B. ( 1979 ). The Pelican Guide to English Literature. The Modern Age Vol.7

17. -Gardner, D. (2011). Fostering Autonomy in Language learning.Gaziantep :Zirve university.

18. -Murtaza, Ghulam\& Noor UlQamarQasmi .(2013). Style and Stylistics : An overview of traditional and linguistic approaches. Galaxy: international multidisciplinary research journal.vol.11. Issue 111.

19. -Orwell, G. (1977).1984.USA: New American Library.

20. -Ransom, John Crowe.(1941).The New Criticism. New York: New Directions. 
21. -Rodger, A (1969), "Linguistics and the Teaching of Literature" in H.Fraser and M.O'Donell, Applied Linguistics and the Teaching of English. London: Longman.

22. -Rubin ,Louis D, Jr."Tory formalists, New York intellectuals, and the New Historical Science of Criticism," Sewanee review 88 (Fall 1980): 674-683.

23. -Sopher, E.(1974). "an Introductory Approach to the Teaching of Scientific English to Foreign Students" in ELT Journal, vol.43 No.2, London: Oxford University Press.

24. -Stein, G. (1909).Three Lives.USA: Penguin Group LTD

25. -Watson, Greg and Sonia Zyngier. (2007). Literature and Stylistics for Language Learners : Theory and Practice .New York: Palgrave MacMillan.

26. -Webster ,R. (1990). Studying Literary theory : An Introduction. Great Britain: Athenaeum.

27. -Widdowson, H.G. (1975). Stylistics and the teaching of Literature. London: Longman LTD.

\section{Factors roles in Communication and}

\section{Appendix 1}

\section{Students' Questionnaire form}

Dear Student:

The following statements are concerned with views about methodologies used in teaching Modern British and American novel. The aim of this research is to reach at positive methods during teaching and keeping the students highly motivated. Please say whether you agree, neutral or disagree with statements given below, using the following scale: $5=$ Strongly agree $4=$ agree , $3=$ Neutral, $2=$ disagree, $1=$ Strongly disagree. Please respond by ticking in the space following the questions or statements or by stating your views in the suitable place.

\begin{tabular}{|c|c|c|c|c|c|c|}
\hline & $\begin{array}{l}\text { Statements \& } \\
\text { Questions }\end{array}$ & $\begin{array}{l}\text { Strongly } \\
\text { Agree(5) }\end{array}$ & $\begin{array}{l}\text { Agree } \\
\text { (4) }\end{array}$ & $\begin{array}{l}\text { Neutra } \\
\text { I (3) }\end{array}$ & $\begin{array}{l}\text { Disagre } \\
\text { e (2) }\end{array}$ & $\begin{array}{l}\text { StronglyDis } \\
\text { agree(1) }\end{array}$ \\
\hline 1 & $\begin{array}{c}\text { Students get the points clearly in } \\
\text { Modern Novel Class. }\end{array}$ & & & & & \\
\hline r & $\begin{array}{l}\text { participating in the Novel class } \\
\text { is more preferable than being a } \\
\text { passive listener. }\end{array}$ & & & & & \\
\hline$\mu$ & $\begin{array}{l}\text { Students all hear the instructor's } \\
\text { voice clearly during lecturing. }\end{array}$ & & & & & \\
\hline$\xi$ & $\begin{array}{l}\text { Which Method is preferable in } \\
\text { teaching modern novel? }\end{array}$ & & & & & \\
\hline - & $\begin{array}{l}\text { What are the difficult points in } \\
\text { understanding during teaching } \\
\text { modern novel? }\end{array}$ & & & & & \\
\hline 7 & $\begin{array}{l}\text { What are the positive or negative } \\
\text { aspects of modern approaches } \\
\text { when applied on the modern } \\
\text { novels through teaching? }\end{array}$ & & & & & \\
\hline $\mathrm{v}$ & $\begin{array}{c}\text { Students face problems during } \\
\text { the Analysis of the text of } \\
\text { modern novels. }\end{array}$ & & & & & \\
\hline$\Lambda$ & $\begin{array}{l}\text { student-centered method in } \\
\text { teaching is necessary. }\end{array}$ & & & & & \\
\hline 9 & $\begin{array}{l}\text { The Instructor's way of } \\
\text { presentation and speed is } \\
\text { suitable. }\end{array}$ & & & & & \\
\hline 1 & Students respond positively & & & & & \\
\hline
\end{tabular}




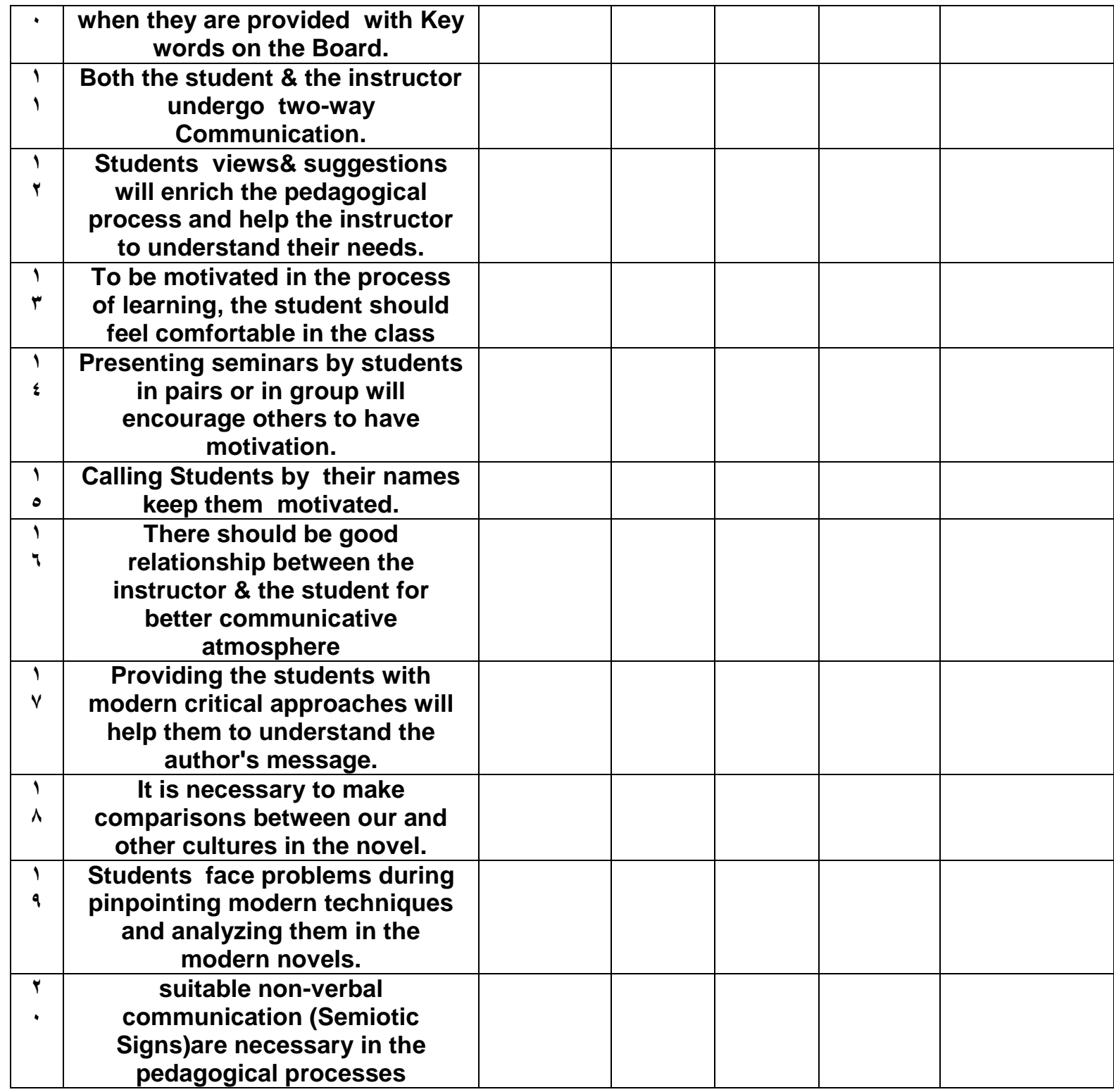

Appendix (2)

Creative writing views assignment

\begin{tabular}{|c|c|}
\hline $\begin{array}{l}\text { Students' views towards } \text { statements or } \\
\text { questions } \\
\text { Date....... } \\
\text { Number } \\
\text { Time....... } \\
\text { Location } \\
\end{array}$ & $\begin{array}{l}\text { These are few Questions for evaluating the } \\
\text { students' knowledge of certain themes in } \\
\text { both Novels and their personal views }\end{array}$ \\
\hline $\begin{array}{l}\text { 1-How can you evaluate Winston as a } \\
\text { protagonist? }\end{array}$ & $\begin{array}{l}\text { 6- Are you convinced with The good } \\
\text { Anna's character depiction? }\end{array}$ \\
\hline 2-write your views on the Big Brother party. & $\begin{array}{l}\text { 7- How can George orwell pinpoints } \\
\text { Allegorical points related to Stalin \& the } \\
\text { Russian revolution? }\end{array}$ \\
\hline $\begin{array}{l}\text { 3-If you were the novelist of Three Lives } \\
\text { what would be your impressions and views } \\
\text { about the end of the novel? }\end{array}$ & $\begin{array}{l}\text { 8-Are you interested in the way Julia } \\
\text { behaves towards the Big Brother party? }\end{array}$ \\
\hline $\begin{array}{l}\text { 4-Do you find any similarities or differences } \\
\text { between your and the target culture? }\end{array}$ & $\begin{array}{l}\text { 9-What are Gertrude Stein's messages in } \\
\text { her novel? }\end{array}$ \\
\hline $\begin{array}{l}\text { 5- Do you prefer the way Stein finishes her } \\
\text { story in Melanctha? }\end{array}$ & $\begin{array}{l}\text { 10-Define distanced characterization in } \\
\text { George Orwell's } 1984 \text {. }\end{array}$ \\
\hline
\end{tabular}




\section{Appendix(3)}

\section{Pinpointing techniques from sample texts (class activities in pairs)}

\begin{abstract}
Dear Students : read and pinpoint the following techniques wherever found in the following samples.

1-Stream of consciousness2- semiotic Expressions3- Metaphorical prose 4multiple point of view 5- Credible plot 6Distanced Characterization 7- Allegory 8irony 9- cinematic View 10- critical point.
\end{abstract}

With those children, he thought, that wretched woman must lead a life of terror. Another year, two years, and they would be watching her night and day for symptoms of unorthodoxy. Nearly all children nowadays were horrible. What was worst of all was that by means of such organizations as the Spies they were systematically turned into ungovernable little savages, and yet this produced in them no tendency whatever to rebel against the discipline of the party. On the contrary, they adored the party and everything connected with it. The songs, the processions, the banners, the hiking, the drilling with dummy rifles, the yelling of slogans, the worship of Big Brother- it was all a sort of glorious game to them (1984 24).
Inside the flat a fruity voice was reading out a list of figures which had something to do with the production of pig iron. The voice came from an oblong metal plaque like a dulled mirror which formed part of the surface of the right-hand wall. Winston turned a switch and the voice sank somewhat, though the words were still distinguishable. The instrument ( thetelescreen, it was called) could be dimmed, but there was no way of shutting it off completely. He moved over to the window: a smallish, frail figure, the meagerness of his body merely emphasized by the blue overalls which were the uniform of the party. His hair was very fair, his face naturally sanguine, his skin roughened by coarse soap and blunt razor blades and the cold of the winter that had just ended (1984 2)

Melanctha Herbert who was Rose Johnson's friend, did everything that any woman could. She tended Rose, and she was patient, submissive, soothing, and untiring, while the sullen, childish, cowardly, black Rosie grumbled and fussed and howled and made herself to be an abomination and like a simple beast(Three Lives 139).

"No, I ain't no common nigger just to go around with any man, nor you Melanctha shouldn't neither," she said one day when she was telling the complex and less sure Melanctha what was the right way for her to do. "No Melanctha, I ain't no common nigger to do so, for I was raised by white folks. You know very well Melanctha that l'se always been engaged to them."(Three Lives 145) 
Appendix 4

Students' responses of the Questionnaire form

Out of 40 students some places are neglected by the students referred

to as (0)

\begin{tabular}{|c|c|c|c|c|c|c|}
\hline & $\begin{array}{l}\text { Statements \& } \\
\text { Questions }\end{array}$ & $\begin{array}{l}\text { Strongly } \\
\text { Agree(5) }\end{array}$ & $\begin{array}{l}\text { Agree } \\
\text { (4) }\end{array}$ & $\begin{array}{c}\text { Neutral } \\
\text { (3) }\end{array}$ & $\begin{array}{l}\text { Disagree } \\
\text { (2) }\end{array}$ & $\begin{array}{c}\text { Strongly } \\
\text { Disagree (1) }\end{array}$ \\
\hline 1 & $\begin{array}{c}\text { Students get the points } \\
\text { clearly in Modern Novel } \\
\text { Class. }\end{array}$ & $r \wedge$ & $\cdot$ & $\varepsilon$ & $\varepsilon$ & . \\
\hline$r$ & $\begin{array}{l}\text { participating in the Novel } \\
\text { class is more preferable } \\
\text { than being a passive } \\
\text { listener. }\end{array}$ & $Y \leqslant$ & . & 0 & V & $\cdot$ \\
\hline$r$ & $\begin{array}{l}\text { Students all hear the } \\
\text { instructor's voice clearly } \\
\text { during lecturing. }\end{array}$ & $r \leqslant$ & $\cdot$ & $r$ & 1 & $\cdot$ \\
\hline$\varepsilon$ & $\begin{array}{l}\text { Which Method is preferable } \\
\text { in teaching modern novel? }\end{array}$ & $\begin{array}{c}(1 \circ \text { keywor } \\
\text { ds }\end{array}$ & $\begin{array}{l}\text { 13tradit } \\
\text { ional }\end{array}$ & $\begin{array}{c}r \\
\text { communi } \\
\text { cative }\end{array}$ & $\begin{array}{c}\text { Student- } \\
\text { (1)centere } \\
\text { d }\end{array}$ & $\begin{array}{l}\text { Power point } \\
\text { projector (1) }\end{array}$ \\
\hline 0 & $\begin{array}{l}\text { What are the difficult points } \\
\text { in understanding during } \\
\text { teaching modern novel? }\end{array}$ & $\begin{array}{c}\text { No } \\
\text { difficulty } \\
(\wedge)\end{array}$ & $\begin{array}{c}\text { s } \\
\text { (keywor } \\
\text { ds)+4 } \\
\text { (text)+1 } \\
\text { (techni } \\
\text { que }\end{array}$ & 9 & $\begin{array}{l}\text { ( Style of } \\
\text { the exam } \\
\text { (3) no time }\end{array}$ & \\
\hline 7 & $\begin{array}{c}\text { What are the positive or } \\
\text { negative aspects of modern } \\
\text { approaches when applied on } \\
\text { the modern novels through } \\
\text { teaching? }\end{array}$ & $\begin{array}{l}\text { ( } 1 \text { rNo } \\
\text { negative } \\
\text { points }\end{array}$ & $\begin{array}{l}\varepsilon \\
\text { Assign } \\
\text { ments }\end{array}$ & $\xi$ & . & . \\
\hline $\mathrm{V}$ & $\begin{array}{l}\text { Students face problems } \\
\text { during the Analysis of the } \\
\text { text of modern novels. }\end{array}$ & $\Lambda$ & $\begin{array}{c}r \\
\text { Someti } \\
\text { mes }\end{array}$ & 1 & $\begin{array}{c}r \\
\text { (Semiotics }\end{array}$ & 9 \\
\hline$\Lambda$ & $\begin{array}{l}\text { student-centered method in } \\
\text { teaching is necessary. }\end{array}$ & 0 & . & $r$ & & $r \leq$ \\
\hline 9 & $\begin{array}{l}\text { The Instructor's way of } \\
\text { presentation and speed is } \\
\text { suitable. }\end{array}$ & YY & . & $\varepsilon$ & $r$ & 0 \\
\hline 1. & $\begin{array}{l}\text { Students respond positively } \\
\text { when they are provided with } \\
\text { Key words on the Board. }\end{array}$ & $r r$ & . & $r$ & 1 & 1 \\
\hline 11 & $\begin{array}{l}\text { Both the student \& the } \\
\text { instructor undergo two-way } \\
\text { Communication. }\end{array}$ & $r^{\prime}$ & $r$ & · & $\cdot$ & 0 \\
\hline$T T$ & $\begin{array}{l}\text { Students views\& } \\
\text { suggestions will enrich the } \\
\text { pedagogical process and } \\
\text { help the instructor to } \\
\text { understand their needs. }\end{array}$ & $\begin{array}{c}\text { 15)( } \\
\text { Preferring } \\
\text { the same } \\
\text { style of } \\
\text { teaching }\end{array}$ & $\begin{array}{c}\text { complai } \\
\text { n from } \\
\text { their } \\
\text { colleag } \\
\text { ues } \\
\text { ideas }\end{array}$ & & $\begin{array}{c}\text { s students } \\
\text { complain } \\
\text { from a } \\
\text { large } \\
\text { amount of } \\
\text { assignmen } \\
\text { ts given by } \\
\text { the } \\
\text { instructor }\end{array}$ & $\begin{array}{c}\text { ( } \\
\text { complains } \\
\text { from } \\
\text { difficult } \\
\text { questions in } \\
\text { written } \\
\text { exams }\end{array}$ \\
\hline 15 & $\begin{array}{l}\text { To be motivated in the } \\
\text { process of learning, the } \\
\text { student should feel } \\
\text { comfortable in the class }\end{array}$ & $r_{1}$ & . & 1 & $\cdot$ & 1 \\
\hline
\end{tabular}




\begin{tabular}{|c|c|c|c|c|c|c|}
\hline $1 \varepsilon$ & $\begin{array}{l}\text { Presenting seminars by } \\
\text { students in pairs or in group } \\
\text { will encourage others to } \\
\text { have motivation. }\end{array}$ & 10 & . & $r$ & $\begin{array}{l}\text { Istudent } \\
\text { prefers the } \\
\text { instructor } \\
\text { to present } \\
\text { the } \\
\text { seminar }\end{array}$ & Ir \\
\hline 10 & $\begin{array}{c}\text { Calling Students by their } \\
\text { names keep them } \\
\text { motivated. }\end{array}$ & 13 & . & $r$ & $\cdot$ & $\mathrm{IV}$ \\
\hline 17 & $\begin{array}{l}\text { There should be good } \\
\text { relationship between the } \\
\text { instructor \& the student for } \\
\text { better communicative } \\
\text { atmosphere }\end{array}$ & $Y \varepsilon$ & . & . & $\cdot$ & $\cdot$ \\
\hline IV & $\begin{array}{l}\text { Providing the students with } \\
\text { modern critical approaches } \\
\text { will help them to understand } \\
\text { the author's message. }\end{array}$ & Y4 & . & 1 & $Y$ & 1 \\
\hline 11 & $\begin{array}{c}\text { It is necessary to make } \\
\text { comparisons between our } \\
\text { and other cultures in the } \\
\text { novel. }\end{array}$ & $r r$ & $\cdot$ & $\cdot$ & $\cdot$ & $r$ \\
\hline 19 & $\begin{array}{l}\text { Students face problems } \\
\text { during pinpointing modern } \\
\text { techniques and analyzing } \\
\text { them in the modern novels. }\end{array}$ & Ir & $r$ & & . & Ir \\
\hline$r_{r}$ & $\begin{array}{c}\text { suitable non-verbal } \\
\text { communication (Semiotic } \\
\text { Signs)are necessary in the } \\
\text { pedagogical processes }\end{array}$ & ro & . & . & . & 7 \\
\hline
\end{tabular}

Appendix (2)

Creative writing views assignment

\begin{tabular}{|c|c|}
\hline $\begin{array}{l}\text { Students' views towards statements or questions } \\
\text { Date....... } \\
\begin{array}{l}\text { Group Number } \\
\text { Lime....... } \\
\text { Location }\end{array}\end{array}$ & $\begin{array}{l}\text { These are few Questions for evaluating the } \\
\text { students' knowledge of certain themes in } \\
\text { both Novels and their personal views }\end{array}$ \\
\hline $\begin{array}{c}\text { 1-How can you evaluate Winston as a } \\
\text { protagonist? }\end{array}$ & $\begin{array}{l}\text { 6- Are you convinced with The good } \\
\text { Anna's character depiction? }\end{array}$ \\
\hline 2-write your views on the Big Brother party. & $\begin{array}{l}\text { 7- How can George orwell pinpoints } \\
\text { Allegorical points related to Stalin \& the } \\
\text { Russian revolution? }\end{array}$ \\
\hline $\begin{array}{l}\text { 3-If you were the novelist of Three Lives what } \\
\text { would be your impressions and views about the } \\
\text { end of the novel? }\end{array}$ & $\begin{array}{l}\text { 8-Are you interested in the way Julia } \\
\text { behaves towards the Big Brother party? }\end{array}$ \\
\hline $\begin{array}{c}\text { 4-Do you find any similarities or differences } \\
\text { between your and the target culture? }\end{array}$ & $\begin{array}{c}\text { 9-What are Gertrude Stein's messages in } \\
\text { her novel? }\end{array}$ \\
\hline $\begin{array}{l}\text { 5- Do you prefer the way Stein finishes her story } \\
\text { in Melanctha? }\end{array}$ & $\begin{array}{c}\text { 10-Define distanced characterization in } \\
\text { George Orwell's } 1984 .\end{array}$ \\
\hline
\end{tabular}

\section{Appendix(3)}

Pinpointing techniques from sample texts (class activities in pairs)

Dear Students : read and pinpoint the following techniques wherever found in the following samples.

1-Stream of consciousness2- semiotic

Expressions3- Metaphorical prose 4multiple point of view 5- Credible plot 6-
Inside the flat a fruity voice was reading out a list of figures which had something to do with the production of pig iron. The voice came from an oblong metal plaque like a dulled mirror which formed part of the surface of the right-hand wall. Winston turned a switch and 
Distanced Characterization 7- Allegory 8irony 9- cinematic View 10- critical point.
With those children, he thought, that wretched woman must lead a life of terror. Another year, two years, and they would be watching her night and day for symptoms of unorthodoxy. Nearly all children nowadays were horrible. What was worst of all was that by means of such organizations as the Spies they were systematically turned into ungovernable little savages, and yet this produced in them no tendency whatever to rebel against the discipline of the party. On the contrary, they adored the party and everything connected with it. The songs, the processions, the banners, the hiking, the drilling with dummy rifles, the yelling of slogans, the worship of Big Brother-it was all a sort of glorious game to them the voice sank somewhat, though the words were still distinguishable. The instrument ( thetelescreen, it was called) could be dimmed, but there was no way of shutting it off completely. He moved over to the window: a smallish, frail figure, the meagerness of his body merely emphasized by the blue overalls which were the uniform of the party.His hair was very fair, his face naturally sanguine, his skin roughened by coarse soap and blunt razor blades and the cold of the winter that had just ended (1984 2)

Melanctha Herbert who was Rose Johnson's friend, did everything that any woman could.

She tended Rose, and she was patient, submissive, soothing, and untiring, while the sullen, childish, cowardly, black Rosie grumbled and fussed and howled and made herself to be an abomination and like a simple beast(Three Lives 139). 
Appendix 4

Students' responses of the Questionnaire form

Out of 40 students some places are neglected by the students referred

to as (0)

\begin{tabular}{|c|c|c|c|c|c|c|}
\hline & $\begin{array}{l}\text { Statements \& } \\
\text { Questions }\end{array}$ & $\begin{array}{l}\text { Strongly } \\
\text { Agree(5) }\end{array}$ & $\begin{array}{l}\text { Agree } \\
\text { (4) }\end{array}$ & $\begin{array}{l}\text { Neutral } \\
(3)\end{array}$ & $\begin{array}{l}\text { Disagree } \\
\text { (2) }\end{array}$ & $\begin{array}{c}\text { Strongly } \\
\text { Disagree (1) }\end{array}$ \\
\hline 1 & $\begin{array}{c}\text { Students get the points } \\
\text { clearly in Modern Novel } \\
\text { Class. }\end{array}$ & $r \wedge$ & $\cdot$ & $\xi$ & $\varepsilon$ & - \\
\hline$r$ & $\begin{array}{l}\text { participating in the Novel } \\
\text { class is more preferable } \\
\text { than being a passive } \\
\text { listener. }\end{array}$ & $r \varepsilon$ & . & 0 & $\mathrm{~V}$ & . \\
\hline$r$ & $\begin{array}{l}\text { Students all hear the } \\
\text { instructor's voice clearly } \\
\text { during lecturing. }\end{array}$ & $\Gamma \varepsilon$ & $\cdot$ & Y & 1 & . \\
\hline$\varepsilon$ & $\begin{array}{l}\text { Which Method is preferable } \\
\text { in teaching modern novel? }\end{array}$ & $\begin{array}{c}(1 \cdot \text { keywor } \\
\text { ds }\end{array}$ & $\begin{array}{l}\text { 13trad } \\
\text { itional }\end{array}$ & $\begin{array}{c}r \\
\text { communic } \\
\text { ative }\end{array}$ & $\begin{array}{l}\text { Student- } \\
\text { (1)centered }\end{array}$ & $\begin{array}{l}\text { Power point } \\
\text { projector (1) }\end{array}$ \\
\hline 0 & $\begin{array}{l}\text { What are the difficult } \\
\text { points in understanding } \\
\text { during teaching modern } \\
\text { novel? }\end{array}$ & $\begin{array}{c}\text { No } \\
\text { difficulty } \\
(\wedge)\end{array}$ & $\begin{array}{c}\varepsilon \\
\text { (keyw } \\
\text { ords) } \\
+4 \\
\text { (text)+ } \\
1 \\
\text { (techn } \\
\text { ique }\end{array}$ & 9 & $\begin{array}{l}\text { ( Style of } \\
\text { the exam } \\
\text { (3) no time }\end{array}$ & \\
\hline 7 & $\begin{array}{l}\text { What are the positive or } \\
\text { negative aspects of } \\
\text { modern approaches when } \\
\text { applied on the modern } \\
\text { novels through teaching? }\end{array}$ & $\begin{array}{l}\text { ( IrNo } \\
\text { negative } \\
\text { points }\end{array}$ & $\begin{array}{c}\varepsilon \\
\text { Assig } \\
\text { nment } \\
\text { s }\end{array}$ & $\varepsilon$ & - & - \\
\hline$V$ & $\begin{array}{l}\text { Students face problems } \\
\text { during the Analysis of the } \\
\text { text of modern novels. }\end{array}$ & $\Lambda$ & $\begin{array}{l}r \\
\text { Some } \\
\text { times }\end{array}$ & 1 & $\begin{array}{c}r \\
\text { (Semiotics }\end{array}$ & 9 \\
\hline$\Lambda$ & $\begin{array}{l}\text { student-centered method } \\
\text { in teaching is necessary. }\end{array}$ & 0 & $\cdot$ & $r$ & & $r \varepsilon$ \\
\hline 9 & $\begin{array}{l}\text { The Instructor's way of } \\
\text { presentation and speed is } \\
\text { suitable. }\end{array}$ & YY & $\cdot$ & $\xi$ & $r$ & 0 \\
\hline ! & $\begin{array}{l}\text { Students respond } \\
\text { positively when they are } \\
\text { provided with Key words } \\
\text { on the Board. }\end{array}$ & $r T$ & - & $r$ & 1 & 1 \\
\hline 1 & $\begin{array}{l}\text { Both the student \& the } \\
\text { instructor undergo two- } \\
\text { way Communication. }\end{array}$ & $r \cdot$ & $r$ & . & . & 0 \\
\hline $\begin{array}{l}T \\
\text { r }\end{array}$ & $\begin{array}{l}\text { Students views\& } \\
\text { suggestions will enrich the } \\
\text { pedagogical process and } \\
\text { help the instructor to } \\
\text { understand their needs. }\end{array}$ & $\begin{array}{l}\text { 15)( } \\
\text { Preferring } \\
\text { the same } \\
\text { style of } \\
\text { teaching }\end{array}$ & $\begin{array}{c}\text { r } \\
\text { compl } \\
\text { ain } \\
\text { from } \\
\text { their } \\
\text { collea } \\
\text { gues } \\
\text { ideas }\end{array}$ & & $\begin{array}{c}\text { s students } \\
\text { complain } \\
\text { from a } \\
\text { large } \\
\text { amount of } \\
\text { assignmen } \\
\text { ts given by } \\
\text { the } \\
\text { instructor }\end{array}$ & $\begin{array}{c}(1 \\
\text { complains } \\
\text { from } \\
\text { difficult } \\
\text { questions in } \\
\text { written } \\
\text { exams }\end{array}$ \\
\hline 1 & To be motivated in the & $r 1$ & . & 1 & $\cdot$ & 1 \\
\hline
\end{tabular}




\begin{tabular}{|c|c|c|c|c|c|c|}
\hline$r$ & $\begin{array}{l}\text { process of learning, the } \\
\text { student should feel } \\
\text { comfortable in the class }\end{array}$ & & & & & \\
\hline $\begin{array}{l}1 \\
\varepsilon\end{array}$ & $\begin{array}{l}\text { Presenting seminars by } \\
\text { students in pairs or in } \\
\text { group will encourage } \\
\text { others to have motivation. }\end{array}$ & 10 & . & $r$ & $\begin{array}{l}\text { Istudent } \\
\text { prefers the } \\
\text { instructor } \\
\text { to present } \\
\text { the } \\
\text { seminar }\end{array}$ & Ir \\
\hline $\begin{array}{l}1 \\
1\end{array}$ & $\begin{array}{l}\text { Calling Students by their } \\
\text { names keep them } \\
\text { motivated. }\end{array}$ & 13 & $\cdot$ & $r$ & $\bar{\sigma}$ & IV \\
\hline $\begin{array}{l}7 \\
\end{array}$ & $\begin{array}{l}\text { There should be good } \\
\text { relationship between the } \\
\text { instructor \& the student for } \\
\text { better communicative } \\
\text { atmosphere }\end{array}$ & $r \varepsilon$ & $\cdot$ & $\cdot$ & . & $\cdot$ \\
\hline$\frac{1}{v}$ & $\begin{array}{l}\text { Providing the students with } \\
\text { modern critical approaches } \\
\text { will help them to } \\
\text { understand the author's } \\
\text { message. }\end{array}$ & Y4 & $\cdot$ & 1 & $r$ & 1 \\
\hline $\begin{array}{l}1 \\
1\end{array}$ & $\begin{array}{c}\text { It is necessary to make } \\
\text { comparisons between our } \\
\text { and other cultures in the } \\
\text { novel. }\end{array}$ & rY & . & . & . & $r$ \\
\hline $\begin{array}{l}1 \\
9\end{array}$ & $\begin{array}{l}\text { Students face problems } \\
\text { during pinpointing modern } \\
\text { techniques and analyzing } \\
\text { them in the modern novels. }\end{array}$ & IT & $\mu$ & &. & IT \\
\hline $\begin{array}{l}r \\
r\end{array}$ & $\begin{array}{l}\text { suitable non-verbal } \\
\text { communication (Semiotic } \\
\text { Signs)are necessary in the } \\
\text { pedagogical processes }\end{array}$ & ro & $\cdot$ & . &. & 7 \\
\hline
\end{tabular}

